\title{
Comparative study of post-partum intra uterine contraceptive device insertion and interval intra uterine contraceptive device insertion in a tertiary care hospital
}

\author{
Manimegalai R.*, Suganthi R.
}

Department of Obstetrics and Gynecology, Government Mohan Kumaramangalam Medical College, Salem, Tamilnadu, India

Received: 09 May 2017

Accepted: 03 June 2017

\section{*Correspondence:}

Dr. Manimegalai R.,

E-mail: krmanimegalai@gmail.com

Copyright: ( ) the author(s), publisher and licensee Medip Academy. This is an open-access article distributed under the terms of the Creative Commons Attribution Non-Commercial License, which permits unrestricted non-commercial use, distribution, and reproduction in any medium, provided the original work is properly cited.

\section{ABSTRACT}

Background: NFHS (National Family Health Survey) 2005-2006 in India revealed that the contraceptive prevalence rate is $53.5 \% .10 \%$ of all pregnancies are mistimed and $11 \%$ of all pregnancies are unwanted in India. Objective of present study was to compare the benefits and complications of postpartum IUCD insertion (PPIUCD) over interval IUCD insertion in a tertiary care hospital.

Methods: It is a retrospective study conducted in the Department of Obstetrics and Gynecology, Govt. Mohan Kumaramangalam Medical College, Salem from 2009-2014. The cases of interval IUCD for the year 2009-2014 and PPIUCD cases for the year 2012-2014 both vaginal insertion and intracaesarean insertion were taken for study. Complications, benefits and reasons for removal were compared between the two groups.

Results: The total number of cases of IUCD insertion significantly increased after the introduction of PPIUCD programme in 2012. The acceptance of IUCD insertion was steadily increasing after the introduction of PPIUCD even though the follow up of PPIUCD cases was less (32\%). The rate of removal in patients who came for follow up was less in PPIUCD group (18\%) compared to interval IUCD cases $(57 \%)$ when the reason was menorrhagia. The most common reason for removal was menorrhagia in interval IUCD patients. Abdominal pain was the most common reason for removal in PPIUCD patients. The rate of expulsion was higher in PPIUCD (6\%) compared to interval IUCD patients $(<1 \%)$. No cases of perforation and no cases of pregnancy in situ were reported in PPIUCD cases during the study period. Even though the rate of infection and missing strings were higher in PPIUCD patients when compared to interval IUCD patients who came for follow up the number of women with infection in PPIUCD patients is less and easily managed with appropriate antibiotics.

Conclusions: In India PPIUCD insertion soon after delivery is a safe, effective, reversible and reliable method of long term contraception. Both vaginal and intracaesarean insertions are safe, efficacious and convenient even though there are few complications which are easily manageable. There are no incidences of perforations, pregnancy in situ, ectopic pregnancy and low rates of infection. Hence PPIUCD is a promising approach to decrease the fertility rate in the field of family planning.

Keywords: CuT380A, Interval IUCD, PPIUCD

\section{INTRODUCTION}

NFHS (National Family Health Survey) 2005-2006 in India revealed that the contraceptive prevalence rate is $53.5 \%$. $10 \%$ of all pregnancies are mistimed and $11 \%$ of all pregnancies are unwanted in India. The number of unintended and un-timed can be brought down by proper utilisation of family planning services. In India, female sterilisation accounts for more than $90 \%$ of contraception but the use of temporary methods of contraception 
remains low which is mostly due to social stigma and cultural misbelieves, lack of knowledge and concern about side effects. ${ }^{1}$ Women's decision on use of contraceptive methods is influenced by several social constrains and social circumstances including family sex composition and gender preference. Worldwide when contraception is used properly and effectively to avoid unwanted pregnancy it can reduce maternal deaths to 25 $35 \%$.

IUCD is a safe and an effective reversible and reliable method of long term contraception. It is convenient to insert and efficient in the post-placental and immediate postpartum periods. ${ }^{2}$ In India delivery is an important opportunity at which the women come into contact with obstetricians and postpartum IUCD insertion is a safe, effective and reversible method to decrease the fertility rate and to decrease maternal morbidity and mortality. Thus, this study aims to compare the complications and benefits of PPIUCD over interval IUCD insertion. ${ }^{3}$ Objective of present study was to compare the benefits and complications of postpartum IUCD insertion (PPIUCD) over interval IUCD insertion in a tertiary care hospital.

\section{METHODS}

It is a retrospective study conducted in the Department of Obstetrics and Gynecology, Government Mohan Kumaramangalam Medical College, Salem from 20092014.

The cases of interval IUCD for the year 2009-2014 and PPIUCD cases for the year 2012-2014 both vaginal insertion and intracaesarean insertion were taken for study.

\section{Inclusion criteria}

- All patients who were willing and fit for IUCD insertion and all postpartum mothers of any age and parity within 48 hours of delivery who gave consent for PPIUCD insertion after counselling were included in the study.

\section{Exclusion criteria}

- Mothers $>48$ hours postpartum, history of prolonged rupture of membranes $>18$ hours, history of chorioamnionitis, PPH, HIV not on ART, diabetes, heart disease, patients at high risk of infection were considered as contraindications for PPIUCD insertion.

The mothers were explained about the benefits and side effects of IUCD and other available methods of contraception. An informed consent was taken and CuT380A was placed high up in the fundus immediately after vaginal delivery by long Kelly's forceps in the lithotomy position (post placental insertion). Those mothers who agreed for PPIUCD within 48 hours postpartum were also inserted in the same manner (immediate postpartum insertion). The strings were not cut and not visible vaginally. Mothers were discharged 48 hours after delivery. In those undergoing LSCS, IUCD were placed high up at the fundus manually holding the IUCD in hand between middle and index fingers of the hand and passed through the uterine incision followed by slow withdrawal of hand. Care was taken to avoid strings to be included during suturing of uterine incision. Strings were pointed towards the cervical canal but not pushed into the canal to avoid infection by vaginal flora and displacement of IUCD. Patients attending family planning OP for interval IUCD insertion were inserted after ruling out pregnancy, genital infections, uterine anomalies, uterine cavity distortions, unexplained vaginal bleeding and other contraindications.

\section{RESULTS}

From 2009 to 2011, 264 patients were inserted interval IUCD. After the introduction of PPIUCD 7340 patients were inserted PPIUCD and 219 patients were inserted interval IUCD from 2012-2014. In this study, it was found the acceptance of IUCD insertion has significantly increased after the introduction of PPIUCD programme from 2012. Chi square test, Fisher exact test were used and $\mathrm{p}<0.05$ is considered significant.

Table 1: Follow up of IUCD cases.

\begin{tabular}{|l|l|l|ll|}
\hline & $\begin{array}{l}\text { Interval IUCD } \\
\text { No. of } \\
\text { cases }\end{array}$ & $\%$ & $\begin{array}{l}\text { PPIUCD } \\
\text { cases }\end{array}$ & $\%$ \\
\hline Total Insertion & 483 & 100 & 7340 & 100 \\
\hline $\begin{array}{l}\text { Cases came for } \\
\text { follow up }\end{array}$ & 299 & 62 & 2348 & 32 \\
\hline
\end{tabular}

Table 2: Comparison between complications of interval IUCD and PPIUCD.

\begin{tabular}{|lllll|}
\hline & $\begin{array}{l}\text { Interval } \\
\text { IUCD }\end{array}$ & \multicolumn{3}{l|}{ PPIUCD } \\
\hline $\begin{array}{l}\text { No. of } \\
\text { cases }\end{array}$ & $\%$ & $\begin{array}{l}\text { No. of } \\
\text { cases }\end{array}$ & $\%$ \\
\hline Abdominal Pain & 125 & 42 & 751 & 32 \\
\hline Bleeding p/v - mild & 170 & 57 & 328 & 14 \\
\hline $\begin{array}{l}\text { Bleeding p/v - } \\
\text { excessive }\end{array}$ & 81 & 27 & 94 & 4 \\
\hline Expulsion & 3 & 1 & 141 & 6 \\
\hline Infection & 3 & 1 & 94 & 4 \\
\hline Perforation & 0 & 0 & 0 & 0 \\
\hline Missing Strings & 6 & 2 & 235 & 10 \\
\hline Pregnancy & 0 & 0 & 0 & 0 \\
\hline
\end{tabular}

Out of 7340 women who had PPIUCD insertion, 2348 came for follow up to our hospital $(32 \%)$. The number of follow up cases is less because these women who came for delivery were mostly referred cases from far different places and the PPIUCD programme is implemented in all 
the taluk hospitals and PHCs and the women go to nearby hospitals for follow up. In the case of interval IUCD the patients who came for follow up is $62 \%$ because the patients were mostly from nearby places (Table 1). Some patients had more than one complication (Table 2).

Table 3: Complications - interval IUCD Vs PPIUCD significance.

\begin{tabular}{|c|c|c|c|c|c|}
\hline & Yes & No & Total & $\begin{array}{l}\text { Chi } \\
\text { square }\end{array}$ & $\mathbf{p}$ \\
\hline \multicolumn{6}{|c|}{ Abdominal pain } \\
\hline $\begin{array}{l}\text { Interval } \\
\text { IUCD }\end{array}$ & 125 & 174 & 299 & \multirow[t]{3}{*}{11.5543} & \multirow[t]{2}{*}{0.000676} \\
\hline PPIUCD & 751 & 1597 & 2348 & & \\
\hline Total & 876 & 1771 & 2647 & & Significant \\
\hline \multicolumn{6}{|c|}{ Missing strings } \\
\hline $\begin{array}{l}\text { Interval } \\
\text { IUCD }\end{array}$ & 6 & 293 & 299 & \multirow[t]{2}{*}{20.5206} & \multirow[t]{2}{*}{0.000006} \\
\hline PPIUCD & 235 & 2113 & 2348 & & \\
\hline Total & 241 & 2406 & 2647 & & Significant \\
\hline \multicolumn{6}{|c|}{ Expulsion } \\
\hline $\begin{array}{l}\text { Interval } \\
\text { IUCD }\end{array}$ & 3 & 296 & 299 & \multirow[t]{3}{*}{12.8987} & \multirow[t]{2}{*}{0.000329} \\
\hline PPIUCD & 141 & 2207 & 2348 & & \\
\hline Total & 144 & 2503 & 2647 & & Significant \\
\hline \multicolumn{6}{|l|}{ Infection } \\
\hline $\begin{array}{l}\text { Interval } \\
\text { IUCD }\end{array}$ & 3 & 296 & 299 & \multirow[t]{2}{*}{6.762} & \multirow[t]{2}{*}{0.009312} \\
\hline PPIUCD & 94 & 2254 & 2348 & & \\
\hline Total & 97 & 2550 & 2647 & & Significant \\
\hline
\end{tabular}

The expulsion rate in patients who came for follow up was significantly higher in PPIUCD group (6\%)compared to interval IUCD patients $(<1 \%)(\mathrm{p}<0.001)$ (Table 3$)$.

Heavy bleeding p/v was found in $57 \%$ of cases of interval IUCD patients who came for follow up. The difference is statistically significant $(\mathrm{p}<0.00001)$ (Table 4).

In present study, the most common reason for removal of IUCD was menstrual disturbances in the interval IUCD patients (Table 5).

The rate of removal in patients who came for follow up in PPIUCD group (18\%) was significantly less compared to interval IUCD (59\%) when the reason was excessive and prolonged bleeding $(\mathrm{p}<0.01)$ (Table 6).

In the PPIUCD group the most common reason for removal was abdominal pain (42\% compared to $33 \%$ in interval IUCD) ( $p=0.21313$ ) which is not statistically significant (Table 6).

Other reasons for removal were partial expulsion of IUCD, social causes like pressure from family members and missing strings.

Bleeding was mildly increased and irregular and on and off in $14 \%$ of PPIUCD cases and excessive and/or prolonged bleeding was found in $4 \%$ of PPIUCD cases who came for follow up.

Table 4: Complication-vaginal bleeding-interval IUCD Vs PPIUCD-significance.

\begin{tabular}{|lllllll|} 
& \multicolumn{2}{l}{ Excess vaginal bleeding } & & & This square & P \\
& Mild & Severe & No bleeding & & Total & \\
Interval IUCD & 170 & 81 & 48 & 299 & \multirow{2}{*}{1549.772} & $<0.00001$ \\
\hline PPIUCD & 57 & 27 & 2264 & 2348 & & Significant \\
\hline Total & 227 & 108 & 2312 & 2647 & & \\
\hline
\end{tabular}

No cases of perforation was reported in the PPIUCD cases during the study period. One case of perforation into the uterine wall during insertion was reported in interval IUCD which was removed in the same sitting and reinserted later.

Rate of infection was about $4 \%$ in PPIUCD group and $1 \%$ in interval IUCD group which is statistically significant $(\mathrm{p}<0.01)$. All patients with infection were treated with appropriate antibiotics.

Incidence of missing strings was higher in the PPIUCD cases who came for follow up (10\%) compared to interval IUCD $(2 \%)(\mathrm{p}<0.000001)$.
Table 5. Reason for removal - interval IUCD Vs PPIUCD.

\begin{tabular}{|lllll|}
\hline $\begin{array}{l}\text { Reason for } \\
\text { removal }\end{array}$ & $\begin{array}{l}\text { No. of } \\
\text { cases }\end{array}$ & $\%$ & $\begin{array}{l}\text { No. of } \\
\text { cases }\end{array}$ & $\%$ \\
\hline Abdominal pain & 18 & 33 & 374 & 42 \\
\hline $\begin{array}{l}\text { Excessive } \\
\text { vaginal bleeding }\end{array}$ & 32 & 59 & 161 & 18 \\
\hline Missing strings & 1 & 2 & 89 & 10 \\
\hline Partial expulsion & 0 & 0 & 54 & 6 \\
\hline Infection & 0 & 0 & 36 & 4 \\
\hline Social cause & 3 & 6 & 178 & 20 \\
\hline Total & 54 & 100 & 892 & 100 \\
\hline
\end{tabular}


Table 6. Reason for removal - interval IUCD Vs PPIUCD - significance.

\begin{tabular}{|c|c|c|c|c|c|}
\hline & \multicolumn{3}{|c|}{ Abdominal pain } & \multirow{2}{*}{$\begin{array}{l}\text { Chi } \\
\text { square }\end{array}$} & \multirow[b]{2}{*}{ p } \\
\hline & Yes & No & Total & & \\
\hline \multirow{2}{*}{$\begin{array}{l}\text { Interval } \\
\text { IUCD } \\
\text { PPIUCD }\end{array}$} & 18 & 36 & 54 & \multirow{2}{*}{1.55} & \multirow{2}{*}{0.21313} \\
\hline & 374 & 518 & 892 & & \\
\hline \multirow[t]{3}{*}{ Total } & 392 & 554 & 946 & & $\begin{array}{l}\text { Not } \\
\text { significant }\end{array}$ \\
\hline & \multicolumn{3}{|c|}{$\begin{array}{l}\text { Excessive vaginal } \\
\text { bleeding }\end{array}$} & \multirow{2}{*}{$\begin{array}{l}\text { Chi } \\
\text { square }\end{array}$} & \multirow{2}{*}{$\mathbf{p}$} \\
\hline & Yes & No & Total & & \\
\hline $\begin{array}{l}\text { Interval } \\
\text { IUCD }\end{array}$ & 32 & 22 & 54 & \multirow{2}{*}{53.2477} & \multirow{2}{*}{$<0.00001$} \\
\hline PPIUCD & 161 & 731 & 892 & & \\
\hline \multirow[t]{3}{*}{ Total } & 193 & 753 & 946 & & Significant \\
\hline & \multicolumn{3}{|c|}{ Missing strings } & \multirow{2}{*}{$\begin{array}{l}\text { Chi } \\
\text { square }\end{array}$} & \multirow{2}{*}{$\mathbf{p}$} \\
\hline & Yes & No & Total & & \\
\hline $\begin{array}{l}\text { Interval } \\
\text { IUCD }\end{array}$ & 1 & 53 & 54 & \multirow{2}{*}{3.9053} & \multirow{2}{*}{0.048133} \\
\hline PPIUCD & 89 & 803 & 892 & & \\
\hline \multirow[t]{3}{*}{ Total } & 90 & 856 & 946 & & Significant \\
\hline & \multicolumn{3}{|c|}{ Partial expulsion } & \multirow{2}{*}{$\begin{array}{l}\text { Fisher } \\
\text { exact } \\
\text { test }\end{array}$} & \multirow[b]{2}{*}{$\mathbf{p}$} \\
\hline & Yes & No & Total & & \\
\hline $\begin{array}{l}\text { Interval } \\
\text { IUCD }\end{array}$ & 0 & 54 & 54 & \multirow[t]{2}{*}{0.066975} & \multirow[t]{2}{*}{0.066975} \\
\hline PPIUCD & 54 & 838 & 892 & & \\
\hline \multirow[t]{3}{*}{ Total } & 54 & 892 & 946 & & $\begin{array}{l}\text { Not } \\
\text { significant }\end{array}$ \\
\hline & \multicolumn{3}{|c|}{ Infection } & \multirow{2}{*}{$\begin{array}{l}\text { Fisher } \\
\text { exact } \\
\text { test }\end{array}$} & \multirow[b]{2}{*}{$\mathbf{p}$} \\
\hline & Yes & No & Total & & \\
\hline $\begin{array}{l}\text { Interval } \\
\text { IUCD }\end{array}$ & 0 & 54 & 54 & \multirow[t]{2}{*}{0.259625} & \multirow[t]{2}{*}{0.259625} \\
\hline PPIUCD & 36 & 856 & 892 & & \\
\hline \multirow[t]{3}{*}{ Total } & 36 & 910 & 946 & & $\begin{array}{l}\text { Not } \\
\text { significant }\end{array}$ \\
\hline & Soci & 1 cau & & Chi & p \\
\hline & Yes & No & Total & square & $\mathbf{P}$ \\
\hline $\begin{array}{l}\text { Interval } \\
\text { IUCD }\end{array}$ & 3 & 51 & 54 & 6.8236 & 0.008996 \\
\hline PPIUCD & 178 & 714 & 892 & & \\
\hline Total & 181 & 765 & 946 & & Significant \\
\hline
\end{tabular}

\section{DISCUSSION}

The number of women who had IUCD insertion significantly increased after the introduction of PPIUCD programme because in India delivery is the only time when most women come in contact with obstetricians and they never return seeking contraception advice due to social problems and family commitments and the myths about IUCD.

The expulsion rate was significantly higher in PPIUCD patients $(6 \%)$ compared to interval IUCD patients $(<1 \%)$ who came for follow up. Among the PPIUCD patients expulsion rate was higher in post-placental and immediate postpartum insertions (5\%) than in intracaesarean insertions $(1 \%)$. This was comparable to the study by Celen $\mathrm{S}$ et al, in which one year cumulative expulsion rate was $12.3 \%$ in early post-placental insertion. ${ }^{4}$ This lower expulsion rate in intracaesarean insertion may be due to direct placement of IUCD at the fundus during LSCS.

In present study, the most common reason for removal was abdominal pain (42\%) whereas in the study by Mishra et al excessive bleeding was the most common cause for removal of PPIUCD. ${ }^{5}$ In the study by Goswami et al the significant reason for removal was pressure from family members. ${ }^{6}$ In this study, social causes accounted for $20 \%$ of removal.

In present study, no case of pregnancy with CuT in situ was reported in both groups during follow up whereas in a study by Kantere AV et al there was one case of intra uterine pregnancy with $\mathrm{CuT}$ in situ out of 52 followed up patients. $^{7}$

In present study incidence of missing strings was $20 \%$ in PPIUCD patients who came for follow up and $1 \%$ in interval IUCD patients. This was contradictory to the study by Nelson et al who found strings in all the cases inserted. $^{8}$

No cases of perforation were reported in PPIUCD patients who came for follow up. This reduced risk of uterine perforation was due to the thick wall of uterus in the immediate postpartum period. This is in accordance with the study of El Shafei MM et al where no perforations were observed in both groups. ${ }^{9}$ In present study one case of perforation into the uterine wall was observed during interval IUCD insertion and $\mathrm{CuT}$ was removed in the same sitting. ${ }^{10}$

The removal of IUCD due to bleeding complaints was more in interval IUCD $(57 \%)$ than in PPIUCD patients $(18 \%)$. This may be due to the fact that many PPIUCD patients were in the period of lactational amenorrhea and hence there was reduced perception of bleeding.

\section{CONCLUSION}

In a developing country like India where many women come in contact with obstetricians only at the time of delivery, PPIUCD insertion is a convenient and easily acceptable method of long term reversible contraception. Whatever may be mode of delivery PPIUCD is safe and cost effective. There are few complications like bleeding, abdominal pain which can be easily managed with drugs. There are no reported incidences of perforation, pregnancy with IUCD in situ, low rate of expulsion, pelvic infection and ectopic pregnancy. PPIUCD insertion is a promising approach in the field of family planning to decrease the fertility rate and to control the 
increase in population. It can be used to reduce the percent with an unmet need for family planning.

\section{ACKNOWLEDGMENTS}

Authors would like to thank Dean, Govt. Mohan Kumaramangalam Medical College, Salem and HOD, Department of Obstetrics and Gynecology for the encouragement and support. Authors also thank the staff of family planning department for their assistance in compiling the data required for the study.

Funding: No funding sources

Conflict of interest: None declared

Ethical approval: Not required

\section{REFERENCES}

1. Pathak KB, Feeney G, Luther NY. Accelerating India's fertility decline: the role of temporary contraceptive methods. Natl Fam Health Surv Bull. 1998;9:1-4

2. Kapp N, Kurtis KM. Intrauterine device insertion during the postpartum period:a systemic review. Contraception. 2009;80:327-36.

3. Shukla M, Qureshi S, Chandrawati. Postplacental intrauterine device insertion: a five year experience at a tertiary care centre in North India. Indian J Med Res. 2012;136:432-5

4. Çelen Ş, Möröy P, Sucak A, Aktulay A, Danışman N. Clinical outcomes of early postplacental insertion of intrauterine contraceptive devices. Contraception. 2004;69(4):279-82.

5. Mishra S. Evaluation of safety, efficacy, and expulsion of post-placental and intra-cesarean insertion of intrauterine contraceptive devices (PPIUCD). J Obstet Gynecol India. 2014;64(5):33743.

6. Goswami G, Yadav K, Patel A. A Prospective Study to Evaluate Safety, Efficacy and Expulsion Rate of Post Placental Insertion of Intra Uterine Device. J Evol Med Dent Sci. 2015;4(56):9770-74.

7. Kanhere A, Pateriya P, Jain M. Acceptability and Feasibility of Immediate post-partum IUCD insertion in a tertiary care centre in Central India. Int J Reprod Contracept Obstet Gynecol. 2015;4(1):1.

8. Nelson AL, Chen S, Eden R. Intraoperative placement of the Copper T380A intrauterine devices in women undergoing elective caesarean delivery: a pilot study. Contraception. 2009;80:81-3.

9. El-Shafei mm, Marshali A, Hassan F O, El-Boghdadi L, El-Lakkany N. Postpartum and postabortion IUCD insertion unmet needs of safe reproductive health: 3 years experience od a Mansoura University Hospital Egypt. Obstet Gynecol. 2000;26:253-62.

10. Harrison - Woolrych M, Ashton J, Coulter D. Uterine perforation on intrauterine device insertion: is the incidence higher than previously reported? Contraception. 2003;67(1):53-6.

Cite this article as: Manimegalai R, Suganthi R. Comparative study of post-partum intra uterine contraceptive device insertion and interval intra uterine contraceptive device insertion in a tertiary care hospital. Int J Reprod Contracept Obstet Gynecol 2017;6:2760-4. 